\title{
EXPERIMENTAL INVESTIGATION ON EXISTING PRECAST PRC ELEMENTS STRENGTHENED WITH CEMENTITIOUS COMPOSITES
}

\author{
INVESTIGACIÓN EXPERIMENTAL SOBRE ELEMENTOS \\ PRC PREFABRICADOS EXISTENTES REFORZADOS \\ CON COMPUESTOS CEMENTICIOS
}

\author{
CARLOS PELLEGRINO', GIORGIO GIACOMIN², RAFAEL ALBERTO PERLO 3 \\ 1 University of Padova. Italia. carlo.pellegrino@unipd.it \\ 2 G\&P Intech s.r.l. Italia. g.giacomin@gpintech.com \\ 3 Phoenix S.A. Argentina. rap@typphoenix.com.ar
}

RESUMEN

Existen varias investigaciones experimentales sobre el polímero reforzado con fibra (PRF), con el objetivo de comprender su comportamiento cuando se aplican como refuerzo de elementos de hormigón armado, pero hay muy pocos datos disponibles sobre el reforzamiento de elementos a escala real con materiales compuestos cementicios. En particular, las formulaciones de código de diseño son escasas o inexistentes.

En este estudio se investigó el comportamiento de cuatro vigas TT pretensadas tomados de un edificio industrial existente. Uno de ellos se consideró como viga TT no reforzada de control, mientras que los otros se reforzaron con diferentes técnicas, concretamente con laminados FRP (pegados con resina epóxica), fibras de carbono con matriz cementicia y fibras de acero con matriz cementicia. Cada material involucrado en este estudio también se caracterizó mecánicamente para obtener las principales propiedades físicas. Se obtuvieron especímenes adecuados de la viga TT existente para caracterizar el hormigón y las barras de acero de refuerzo.

PALABRAS CLAVE: compuesto de cemento, elementos prc prefabricados existentes, fibras de carbono, fibras de acero.
ABSTRACT

A number of experimental investigations on fibre reinforced polymer (FRP), with the aim of understanding their behaviour when applied as strengthening of reinforced concrete elements, are available in the literature but very few information is available on strengthening real-scale elements with cementitious composites. In particular design code formulations are scanty or non-existent.

In this study the behaviour of four precast pre-stressed TT beams taken from an existing industrial building was investigated. One of them was considered as control unstrengthened TT beam, whereas the others were strengthened with different techniques, namely with FRP laminates (glued with epoxy resin), carbon fibres with cementitious matrix and steel fibres with cementitious matrix. Each material involved in this study was also mechanically characterized to obtain the main physical properties. Adequate specimens were obtained from the existing TT beam to characterize the concrete and the reinforcing steel bars.

KEYWORDS: cementitious composite, existing precast prc elements, carbon fibres, steel fibres. 
INTRODUCTION

A number of existing Reinforced Concrete (RC) structures need rehabilitation or strengthening because of improper design or construction, change of the design loads, damage caused by environmental factors or seismic events. Strengthening by means of fibre reinforced polymers (FRP), has been widely studied in the last few decades, and some studies have resulted in the first design guidelines for strengthened concrete. ACI 440.2R-08 (ACI Committee 440 2008) [1], European fib- T.G. 9.3 (fib T.G. 9.3 2001) [2], CNR-DT 200-04 (Italian Research Council Advisory Committee on Technical Recommendations for Construction 2004) [3], are examples of such guidelines. Strengthening by means of cementitious composite reinforcement is a more recent technique about which there is very few information available in literature, particularly in relation to steel fibres and design code formulations on these kind of strengthening applications. Furthermore, experimental investigations on real-scale flexural elements are very few [4]. Some examples of studies on composites with cementitious matrix can be found in [5-9], whereas recent experimental applications of mortars for rehabilitating existing structural elements developed at the University of Padova can be found in $[10,11]$.

This paper describes the experimental investigation on four precast pre-stressed TT beams taken from an existing industrial building where they were used as roof elements.

One of them was taken as control unstrengthened TT beam, whereas the others were strengthened by different techniques, namely (1) with a ply of CFRP laminate glued with epoxy resin at the bottom of the webs, (2) with carbon fibre in a cementitious matrix and (3) with steel fibre in a cementitious matrix. A four-point loading configuration was adopted for each test (figure 1).

Each material involved in this study was mechanically characterized. In particular cylindrical concrete specimens were taken from the precast pre-stressed TT beams to characterize the concrete and adequate specimens of the steel reinforcement were extracted and tested as well.

\section{EXPERIMENTAL PROGRAM} GEOMETRY OF TT BEAMS

Four precast pre-stressed TT beams taken from an existing industrial building were investigated. The beams have a length of $1167 \mathrm{~cm}$, a width of $128.5 \mathrm{~cm}$ and a height of $40 \mathrm{~cm}$ (with a $5 \mathrm{~cm}$ thickness of the flange). Each web has a width of $9.5 \mathrm{~cm}$ and its axis stays $510 \mathrm{~cm}$ from the cross-section midpoint. Each of the webs includes stirrups $\phi 5 / 200 \mathrm{~mm}$ and longitudinal ordinary steel reinforcement.

consisting in $2 \phi 5$ at the upper side and $2 \phi 5$ at the lower side, two strands with a diameter of $1 / 2$ " and two with a diameter of $3 / 8$ " placed as in figure 2 .

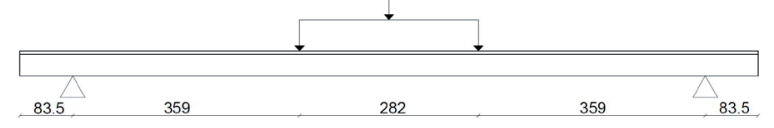

Figure 1. Experimental loading configuration (dimensions in $\mathrm{mm}$ ).

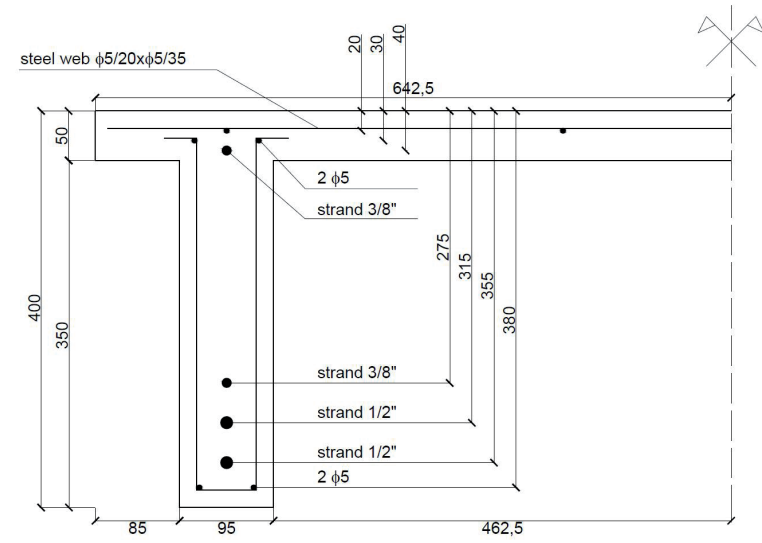

Figure 2. TT beam cross section (dimensions in $\mathrm{mm}$ ).

\section{STRENGTHENING CONFIGURATIONS}

One of the precast pre-stressed TT beams taken from the industrial building, hereafter indicated with TT00, was taken as control unstrengthened TT beam to compare its behaviour with the strengthened beams.

The beam indicated as TTcl was strengthened by means of a carbon laminate bonded at the bottom of the webs. The carbon laminate named CFK 150/2000 has a thickness of $1.4 \mathrm{~mm}$ and a width of $60 \mathrm{~mm}$. It was bonded along the length of the webs until a distance of about 10 $\mathrm{cm}$ from the supports. The concrete surface was prepared/smoothed before the strengthening application. A ply of Resin Primer and a ply of epoxy resin (named Resin 90) were applied and the CFRP laminate, accurately cleaned, was finally applied over the adhesive and pressed by means of a rubber hammer.

The third precast pre-stressed TT beam, hereafter indicated as TTcf, was strengthened by two plies of carbon fibres type C-NET 200U bonded to bottom and lower side part of the webs by means of a cementitious mortar (named Con- 
crete Rock V2). It was chosen to apply two plies of carbon fibres web to reach a theoretical flexural strength close to the previous strengthened beam. The fibre has a thickness of $0.117 \mathrm{~mm}$. The two-components mortar Concrete Rock V2 used for this application includes fine aggregates, inorganic binders and polymeric fibres. The concrete surface was mechanically smoothed before the application to improve the adhesion. The second ply was applied over an additional mortar cover placed on the first ply. A final mortar cover was applied to protect the fibres.

The fourth precast pre-stressed TT beam, hereafter indicated as TTsf, was strengthened by a ply of a steel fibre type Steel Net 190 bonded to bottom and lower part of the webs by means of the cementitious mortar used for the previous beam. The steel fibres have a thickness of 0.24 $\mathrm{mm}$. The procedure for strengthening was similar to the previous beam.

In figure 3 the three strengthening configurations are shown.
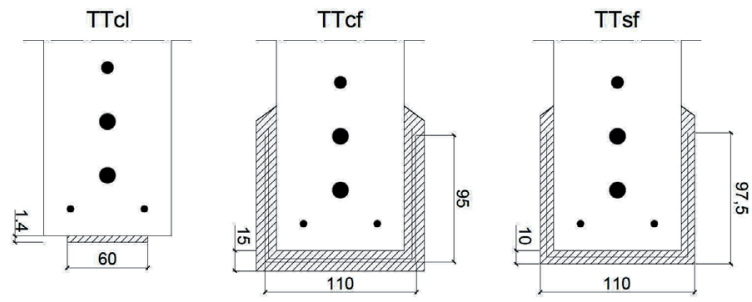

Figure 3. Strengthening configuration (dimensions in $\mathrm{mm}$ ).

MATERIAL CHARACTERIZATION

Each material involved in the experimental program was tested to obtain its main physical properties. Adequate specimens were extracted from the existing TT beam to characterize the concrete and the reinforcing steel bars. These specimens, after a process of mechanical rectification, were instrumented and tested in compression to obtain the compressive strength, fc, and the elastic modulus, Ec according to ASTM C42/C42M [12] and Eurocode 2 [13]. The mean values obtained by the tests are: $\mathrm{fc}=59.9 \mathrm{MPa}$ and $\mathrm{EC}=41809 \mathrm{MPa}$.

Adequate specimens of steel bars were taken from the beams' flanges and webs and subjected to tensile tests. The following mean values of the yield and ultimate tensile strength were obtained: $\mathrm{fy}=612 \mathrm{MPa}$ and $\mathrm{fu}=647 \mathrm{MPa}$. It was not possible to extract the steel strands, hence typical values are assumed for the calculations.

The carbon laminates were tested in tension to obtain the mean values of the ultimate strength, the ultimate strain and elastic modulus.
The following results were obtained: ultimate stress $\mathrm{ff}=2539 \mathrm{MPa}$, ultimate strain $\varepsilon f=0.0165$, elastic modulus $\mathrm{Ef}=168000 \mathrm{MPa}$.

Regarding the carbon fibres, mechanical characteristics given by the manufacturer were assumed. The steel fibres were mechanically characterized by means of tensile tests on single wires. The mean value of the tensile strength of a single strand was $\mathrm{fu}, \mathrm{sf}=3156 \mathrm{MPa}$.

The mortar used for the experimentations is the same for carbon and steel fibres and it was characterized in compression and bending according to UNI EN 1015-11 2007 [14]. The prismatic specimens had a square cross section with a $40 \mathrm{~mm}$ side and a length of $160 \mathrm{~mm}$. The results provided the mean value of the force at flexural failure Fflex $=8437 \mathrm{~N}$ and the mean value of the compressive strength of the mortar $\mathrm{fc}$, mortar $=$ 45.3 MPa. (Class R4 EN 1504-3).

\section{EXPERIMENTAL RESULTS}

The load was applied using a four point loading configuration applying the force at the positions corresponding to web axes. The supports were realized using two steel beams and a ply of rubber was placed between the beams and the supports to avoid local failure phenomena.

The precast pre-stressed TT beams were instrumented by means of linear variable differential transducers (LVDT) to measure deflections, strain transducers DD1 on the concrete to measure crack amplitudes and compressive strains, and strain gauge sensors on the CFRP laminate (only in the beam TTcl).

In figure 4 load vs. deflection diagrams for the control and strengthened beams are shown. The control beam TT00 showed the typical flexural failure with significant deflections at failure. The ultimate load of the control beams was $140 \mathrm{kN}$. In figure 5 the unstrengthened TT00 beam near failure was shown.

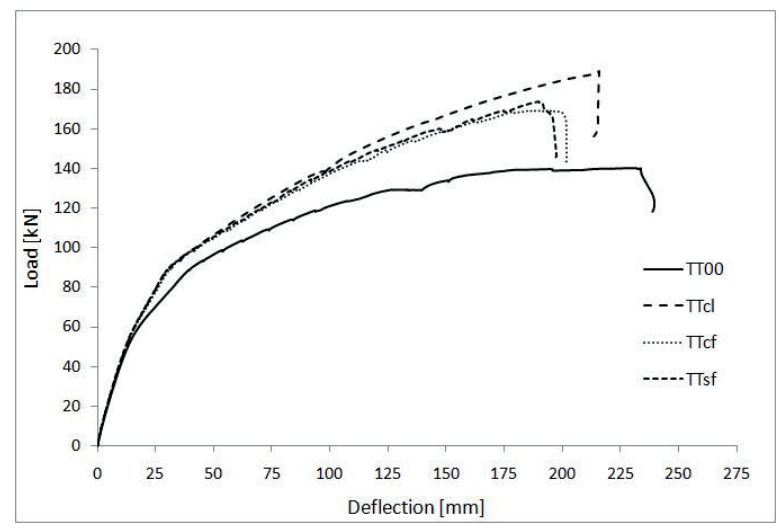

Figure 4. Load - deflection curves for control and strengthened TT beams. 


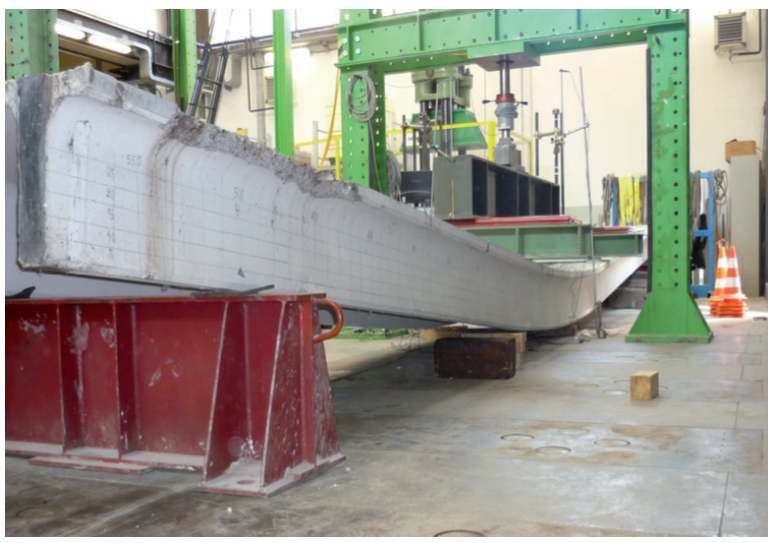

Figure 5. Failure of the control unstrengthened TT beam.

The precast pre-stressed TT beam TTcl, strengthened by means of a CFRP laminate bonded at the bottom of the webs, was instrumented by means of 10 strain gauges sensors placed on the CFRP laminates at various positions. The midspan deflection was measured by means of 2 LVDTs. 4 DD1 were used to measure the concrete compressive strain at midspan. Two of them were placed over the flange, the other two at lateral sides of the flange.

The failure occurred suddenly at a load of 189 $\mathrm{kN}$, with a corresponding midspan deflection of $214.5 \mathrm{~mm}$. The collapse was caused by the sudden debonding along $2 / 3$ of the span of one of the 2 CFRP laminates bonded to the webs. The concrete surface was particularly peeled near the midspan (figure 6).

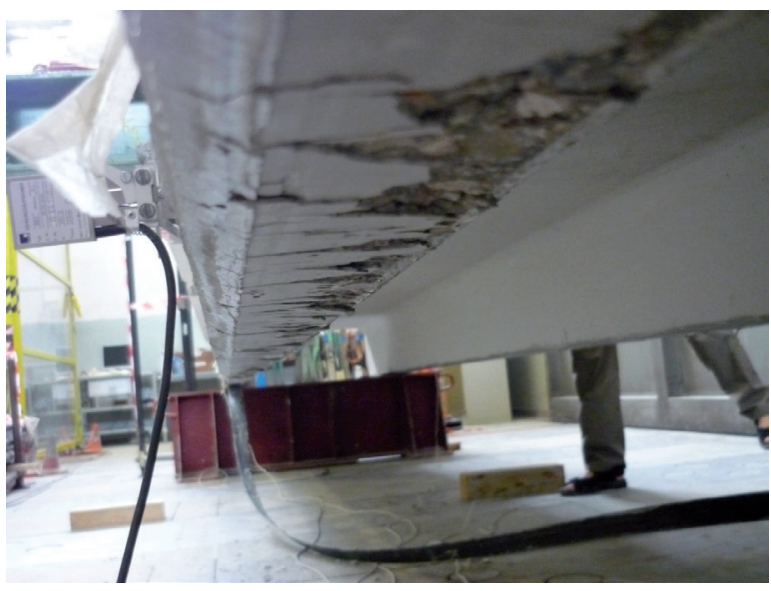

Figure 6. Detail of the TTcl beam after the test.

The third precast pre-stressed TT beam (TTcf), strengthened by means of 2 plies of carbon fibres in a cementitious matrix, was instrumented by means of LVDTs to measure deflections and strain transducers DD1 on the concrete to measure crack amplitudes and compressive strains.
The collapse of the TTcf beam was caused by the detachment of the cementitious composite near the midspan. A diffuse cracking pattern was observed and some portions of the mortar cover were peeled out, particularly near the midspan. Some parts of the carbon fibres were completely broken (figure 7). The ultimate load of the TTcf beam was $169.2 \mathrm{kN}$, whereas the corresponding midspan deflection was $200.9 \mathrm{~mm}$.

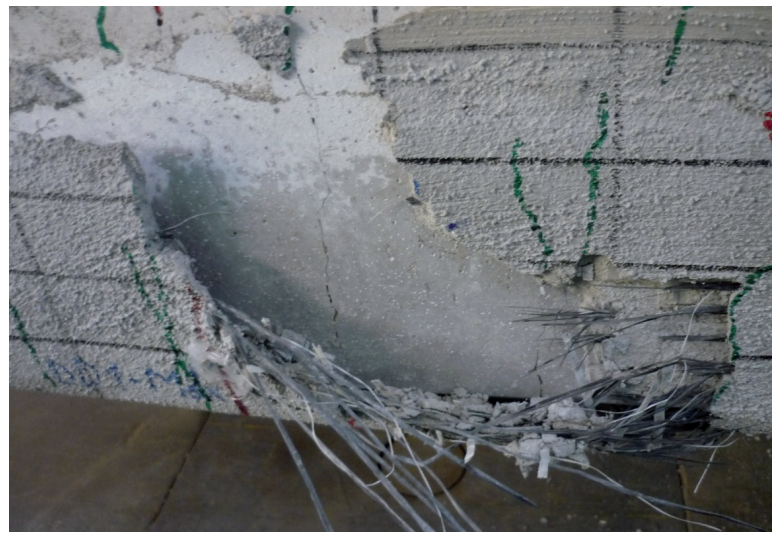

Figure 7. Detail of the fibres after the concrete cover removal.

The fourth precast pre-stressed TT beam (TTsf), strengthened by means of one ply of steel fibre in a cementitious matrix, was instrumented by means of LVDTs to measure deflections and strain transducers DD1 on the concrete to measure crack amplitudes and compressive strains. The TTsf beam collapsed due to debonding of the steel fibres, starting from the end of the beam and propagating along the beam axis. The steel fibre net was particularly damaged at the edges of the webs (figure 8). The ultimate load was $173.6 \mathrm{kN}$, whereas the corresponding midspan deflection was $196.3 \mathrm{~mm}$.

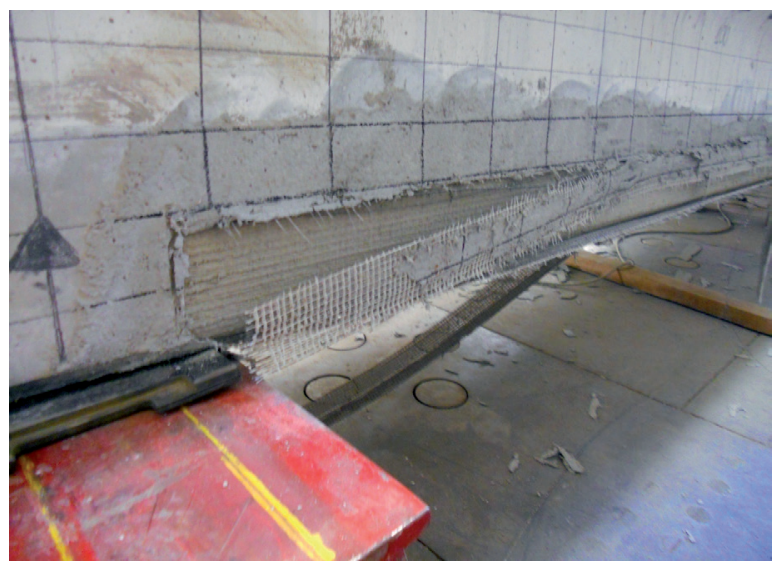

Figure 8. Failure or the cementitious composite strengthening in the beam TTsf. 
CONCLUSION

This study describes the preliminary results of an experimental investigation on four existing precast pre-stressed TT beams taken from an existing industrial building. One of them was taken as control unstrengthened TT beam, whereas the others were strengthened with different techniques, namely with a ply of CFRP laminate glued with epoxy resin, with carbon fibres in a cementitious matrix and with steel fibres in a cementitious matrix. A four-point loading configuration was adopted for each test. The results showed that the failure mode in the beam with externally bonded laminates and in those with cementitious composites was different and that the cementitious composite strengthening provides a significant contribution to the flexural strength of the beams both with carbon and steel fibres. In particular the strengthened beams showed an increase in the ultimate load equal to $35 \%$ for TTcl beam (with externally epoxy bonded laminate), 20\% for TTcf beam (with carbon fibres and cementitious mortar), and 24\% for TTsf beam (with steel fibres and cementitious mortar), with respect to the control beam.

ACKNOWLEDGEMENTS

The authors gratefully acknowledge Mr. Francesco Meneghel and Mr. Nicola Pesce for their contributions in the experimental tests during the activity related to their degree thesis and the technicians of the Laboratory for Structural Materials Testing of the Department of Structural and Transportation Engineering of the University of Padova, particularly Mr. Renzo Segafreddo, for their contribution in the execution of the tests. Lastly, the technical and economical support of G\&P Intech S.r.l. was also acknowledged.

\section{REFERENCES}

1. AMERICAN CONCRETE INSTITUTE (ACI), "Guide for the design and construction of externally bonded FRP systems for strengthening of concrete structure", ACI 440.2R-08, Farmington Hill, Mich., 2008.

2. fib BULLETIN 14, "Externally bonded FRP reinforcement for RC structures”, CH-1015, Lausanne, 2001.

3. CONSIGLIO NAZIONALE DELLE RICERCHE (CNR), "Instructions for design, execution and control of strengthening interventions through fiber-reinforced composites." CNR-DT 200- 04, Consiglio Nazionale delle Ricerche, Rome, Italy, 2004.
4. PELLEGRINO C., MODENA C. "Flexural strengthening of real-scale RC and PRC beams with end-anchored pre-tensioned FRP laminates", ACI Structural Journal, Vol. 106, N. 3, 2009, pp. 319-328.

5. JESSE, F., SCHICKTANZ, K., CURBACH, M., "Obtaining Characteristic Material Strength of Textile Reinforced Concrete (TRC) from $\mathrm{La}^{-}$ boratory Tests", 9th International Symposium on Ferrocement (Ferro9), Bali, May 18-20, 2009, pp. 305-318.

6. JESSE, F., WEILAND, S. AND CURBACH, M. "Flexural strengthening of rc-structures with textile reinforced concrete, Textile Reinforced Concrete (TRC) -- German/International Experience", Proceedings of ACI Fall Convention. Kansas City, November 2005, A. Dubey editors, ACI Special Publication, SP-250CD-4.

7. HÄUßLER-COMBE, U., HARTIG, J. "Bond and failure mechanisms of textile reinforced concrete (TRC) under uniaxial tensile loading", Cement and Concrete Composites, Vol. 2, N. 4, 2007, pp. 279-289.

8. BRUCKNER A., ORTLEPP R., CURBACH M. "Textile Reinforced Concrete for strengthening in bending and shear", Materials and Structures, Vol. 39, N. 8, 2006, pp. 741-748.

9. HEGGER J., WILL N., BRUCKERMANN O., VOSS S. "Load- bearing behaviour and simulation of Textile Reinforced Concrete", Materials and Structures, Vol. 39, 2006, pp. 765- 776.

10. PELLEGRINO C., DA PORTO F., MODENA C. "Rehabilitation of reinforced concrete axially loaded elements with polymer-modified cementitious mortar", Construction and Building Materials, Vol. 23, N. 10, 2009, pp. 3129-3137.

11. PELLEGRINO C., DA PORTO F., MODENA C. "Experimental behaviour of reinforced concrete elements repaired with polymer-modified cementitious mortar", Materials and Structures, Vol. 44, N. 2, 2011, pp. 517-527.

12.ASTM, "Standard test method for obtaining and testing drilled cores and sawed beams of concrete", ASTM C42/C42M-11, American society for testing and materials, 2011.

13. CEN, "Eurocode 2: Design of Concrete Structures - Part 1-1: General Rules and Rules for Buildings," ENV 1992-1-1 2004, Comité Européen de Normalisation, Brussels, Belgium, 2004.

14. UNI, "Methods of test for mortar for masonry - Part 11: Determination of flexural and compressive strength of hardened mortar", UNI EN 1015-11:2007, Ente Nazionale Italiano di Unificazione, 2007. 